\title{
Powered roof support in conditions of mining tremors in Upper Silesian Coal Basin - current state in terms of statistical analysis
}

\begin{abstract}
Coal mining in Upper Silesian Coal Basin (USCB) is conducted in the conditions of frequent mining tremors. The longwall roof support significantly impacts the safety and efficacy of the mining process. The paper presents the assessment of mining tremor hazard, the procedure of designing powered roof supports used in the conditions of tremors, and a method of evaluating supports' resistance to dynamic overloads. The research was based on analyses carried out by the authors on a the data collected during the works carried out by the Department of Extraction Technologies, Rockbursts, and Mining Support. The data was analysed using descriptive statistics.
\end{abstract}

Key words: powered roof support, dynamic overloads, mining tremor hazard

\section{INTRODUCTION}

Powered roof supports are placed on the market in compliance with the requirements of European Union Directives A new powered roof support (PRS) must fulfill the requirements of European Union Directives and harmonized Polish standards. The basic standards of the EN 1804 series that define the mechanical requirements for PRS exclude their application in areas threatened with mining tremors. Polish standards are complemented by the current regulations on occupational health and safety of the relevant Minister [1]. They introduce the requirement for the PRS to be especially protected in conditions of mining tremors hazard. Part of the protection strategy is to determine the safe range of support operation height and to select overload protection means for specific mining and technical conditions [2]. One of the most common methods protecting against dynamic overload involves installing hydraulic valves that limit the pressure in the leg piston space to an acceptable level considering the mechanical strength of a given structure. In other words, the support needs to yield when the dynamic phenomenon occurs.
The yielding protection method used by the Central Mining Institute (GIG) is an analytical method based on selected parameters:

- mining parameters $-n_{t z}$ load coefficient and $g$ roof bearing capacity index,

- operational parameters,

- technical parameters of the support - kinematics, diameters of the legs used, load bearing capacity: initial, working, nominal; $k$ safety factor coefficient and protection applied by hydraulic valves.

In this paper, the current state of the operating powered roof support has been described using statistical methods. The analysis was focused on PRS technical parameters and operational conditions, based on the collected database for the years 2016-2019.

\section{POWERED ROOF SUPPORT DESIGN IN THE CONDITIONS OF TREMOR HAZARD}

Overload can be defined as the "exceeding of the instantaneous nominal load of the support and its components by more than $50 \%$ due to rock mass 
tremors". The adopted definition is consistent with the provisions of the Polish standard PN-EN 18041,2,3+A1 and literature [3].

The consequences of overload include primarily a loss of functionality of the support and its components (steel structure, hydraulic legs, and hydraulics control system) or a threat to overall operational safety (e.g. uncontrolled convergence).

Overload assessment is carried out according to the method developed by GIG as an implementation of the Regulation of the relevant Minister in the field of adaptation of the powered roof support to take over the dynamic loads [1]. Its aim is to determine the safe range of support operation height and to select overload protection for specific geological-mining and technical conditions of support operation [2].

The yielding method used by GIG is an analytical method based on selected mining parameters ( $n_{t z}$ load coefficient, roof bearing capacity index $g$ ) as well as operational and technical parameters of the support and its protection.

The $n_{t z}$ load coefficient defines the increase in the support load due to rock mass tremor with respect to the static load. It depends on the distance from the hypocentre of the tremor to the roof of the longwall and the predicted maximum energy of the tremor. The variability of the $n_{t z}$ index ranges from 1.0 to $1.8 \mathrm{~m}$, according to [4]. The $n_{t z}$ load coefficient is also an important parameter used in determining the roof bearing capacity index $g$ [5-10]. The roof bearing capacity index $g$ defines the roof maintenance conditions:

- $g<0.7$ - caving hazard (the powered roof support does not have a sufficient reserve of support to properly secure the excavation);

- $0.7=g<0.8$ - difficult roof maintenance conditions (although the use a powered roof support in a specific excavation is allowed, it must be remembered that limitations or difficulties in the excavation roof maintenance may occur);

- $g=0.8$ - proper roof maintenance conditions (the support is properly suited to a specific excavation).

For conditions where frequent tremors may occur, it is recommended that the $g$ indicator be $=0.8$, which ensures correct maintenance of the roof. However, it should be noted that the correlation between the $g$ index and the $n_{t z}$ load coefficient is not a linear function and must be considered individually for each case of a new longwall and powered roof support.

The degree of mining tremor hazard in the case of a longwall excavation-based on the value of the $n_{t z}$ load coefficient can be determined as shown in Table 1 .

The values of the $n_{t z}$ load coefficient in the years 2016-2019 are shown graphically in Figure 1.

Table 1

The degree of mining tremor hazard in the case of a longwall excavation based on the value of the $n_{t z}$ load coefficient [4]

\begin{tabular}{|l|c|c|c|c|c|}
\hline Load coefficient $\boldsymbol{n}_{\boldsymbol{t} z}$ & $1.0-1.1$ & $1.0-1.1$ & $1.2-1.3$ & $1.3-1.4$ & $>1.4$ \\
\hline Hazard to the excavation & lack & weak & medium & strong & very strong \\
\hline
\end{tabular}

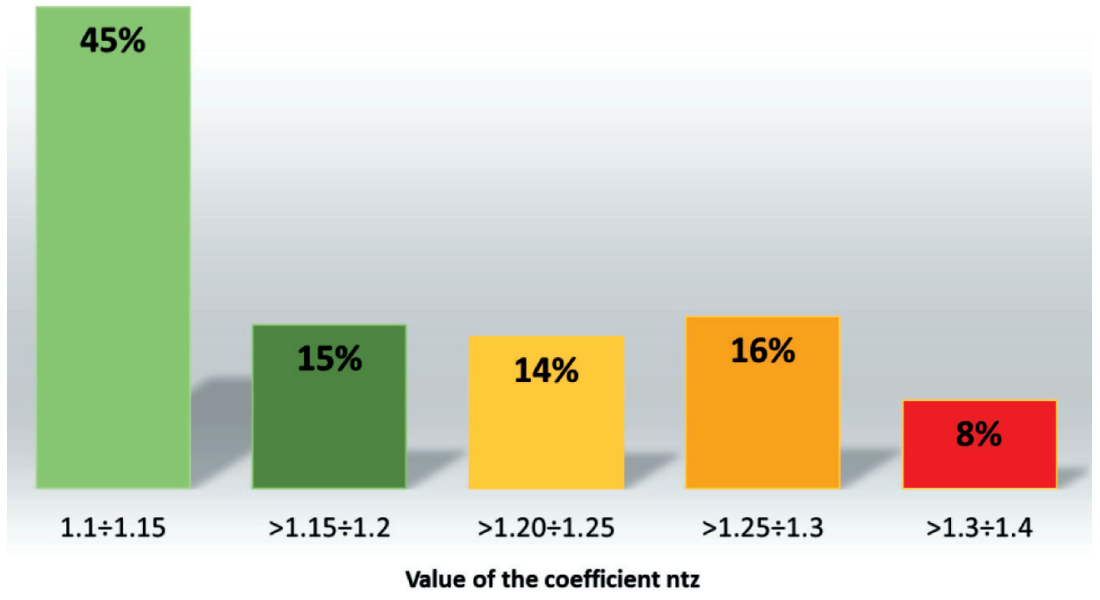

Fig. 1. $n_{t z}$ load coefficient in the years 2016-2019 by GIG 
The data encompasses 266 cases of longwalls excavated under the conditions prevailing in USCB, analysed by the Central Mining Institute as part of research and development works commissioned by mines and roof support manufacturers. The cases concerned the design of a powered roof support and determination of conditions of its protection under specific geological and mining conditions.

The above data demonstrates that $29 \%$ of the longwalls are operating under conditions of medium tremor hazard, and $8 \%$ - high mining tremor hazard. Considering that the mining operations in USCB will be conducted at deeper levels and the tremor hazard tends to intensify with increasing depth, it should be concluded that the percentage of longwalls with a high risk of rock mass tremors will be higher.

GIG's yielding protection method is based on the disturbed rock mass model developed by A. Biliński and the flat model of support with concentrated constants and one degree of freedom. The following dependencies are applied [2, 4, 11-13]:

$$
\begin{aligned}
f(t)= & \frac{1}{\cos (90-\alpha)} . \\
& \cdot\left(F_{w}+F_{d}\left(1+k_{d} e^{-\delta t} \sin (\omega t-\varphi)\right)[\mathrm{N}]\right.
\end{aligned}
$$

where:

$$
\begin{aligned}
f(t), F_{w}, F_{d}- & \text { forces, respectively: leg, initial and } \\
& \text { dynamic load }[\mathrm{N}], \\
\delta- & \text { system damping factor }\left[\mathrm{s}^{-1}\right], \\
k_{d}- & \text { calculation factor, } \\
\omega- & \text { angular velocity }\left[\mathrm{rad} / \mathrm{s}^{-1}\right], \\
\varphi- & \text { angle of force shift in the leg in rela- } \\
& \text { tion to the loading force }[\mathrm{rad}], \\
\alpha- & \text { angle of inclination of the leg in re- } \\
& \text { lation to the floor base, degree. }
\end{aligned}
$$

Here, the maximum force is calculated for each case and refers to the nominal capacity of the leg, for a given working height, the value of the $n_{t z}$ indicator and the flow in the overload protection system.

In addition, in the case of roofs which are difficult to be caved (which do not cave-in behind the powered supports line), it is proposed to carry out additional calculations using the evaluation of the force of the rock mass-section system according to dependence (2) $[4,14]$, in order to check the flows in the system protecting the leg.

$$
Q \geq \frac{F_{r}\left(n_{t z}^{2}-n_{t z}\right)}{2 P_{r} \cos \alpha} \cdot 6 \cdot 10^{4}\left[\mathrm{dm}^{3} \min ^{-1}\right]
$$

where:

$Q$ - flow in the leg protection system $\left[\mathrm{dm}^{3} \mathrm{~min}^{-1}\right]$,

$F_{r}$ - working bearing capacity of the roof support $[\mathrm{N}]$,

$n_{t z}-$ load coefficient,

$P_{r}-$ nominal bearing capacity of the leg $[\mathrm{N}]$.

\section{PERFORMANCE AND TECHNICAL PARAMETERS OF CURRENTLY USED POWERED ROOF SUPPORTS}

In the years 2016-2019, the Department of Extraction Technologies, Rockbursts and Mining Support, GIG, has carried out over 550 research and development works, including 266 works concerning the determination of the support protection by yielding and its application in specific geological and mining conditions.

The analysis of studies concerning the powered roof support applied in seams with tremor hazard shows that the support most frequently used in USCB is shield support with two hydraulic legs. The most popular are double-telescopic hydraulic legs with a bottom valve, and their share in the whole analysed group is as much as $73 \%$ (Fig. 2).

Single-telescopic legs with a mechanical extension are used less frequently, but their share is still substantial $-16 \%$. They are followed by double-telescopic legs $(7 \%)$ with the so-called third piston. The remaining $5 \%$ are whose share in the group was the smallest, including double-telescopic legs with a bottom valve and a mechanical/hydraulic extension, as well as legs with a floating piston.

The percentage division of double-telescopic legs according to their first-degree diameter in the analysed set is shown in Figure 3.

Currently, the most commonly used legs in the mines of USCB are those with first-stage diameters equal to $0.30 \mathrm{~m}$ and $0.32 \mathrm{~m}$, which is related to deteriorating geological and mining conditions. A large group are also legs with a diameter of $0.25 \mathrm{~m}$, which is related to repairs of previously operated roof supports.

More than $60 \%$ of ongoing mining activity takes place in the conditions of tremor hazard, which is confirmed by the fact that mines increasingly often purchase powered roof supports with legs having diameters of $\geq 0.30 \mathrm{~m}$, in order to obtain a greater loadbearing capacity for the supports and ensure proper conditions for maintaining the longwall roof. 


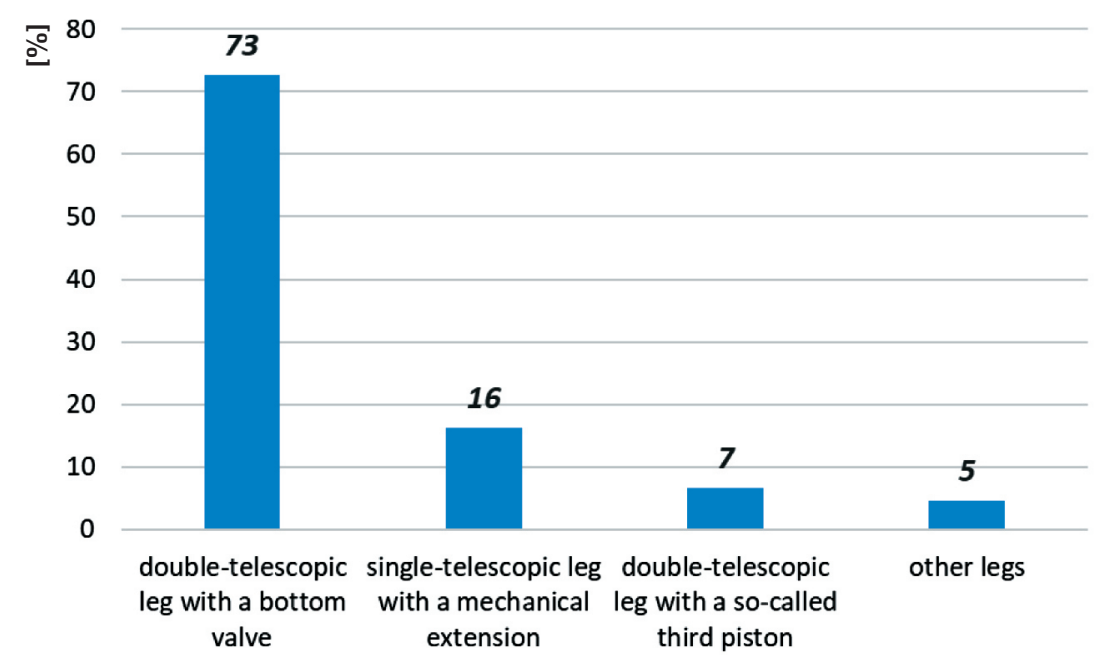

Fig. 2. Percentage share of various types of legs of the powered roof support used in 2016-2019

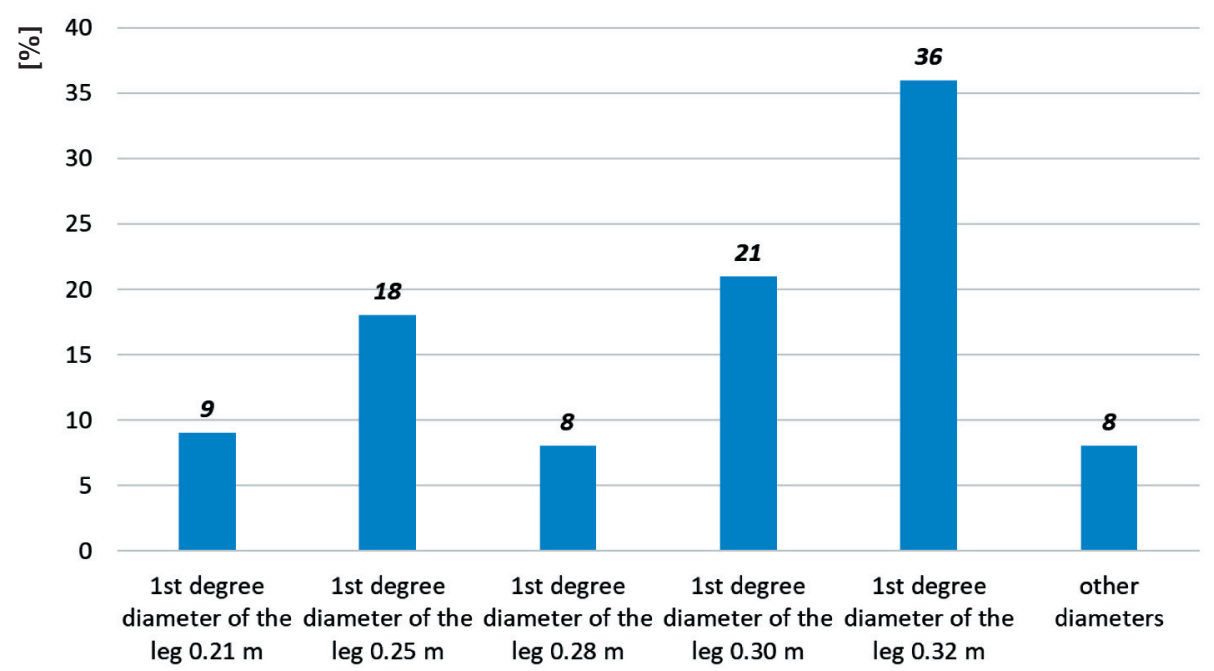

Fig. 3. Percentage share of double-telescopic legs with the first-degree diameter in the analysed set

The remaining $8 \%$ of the analysed cases, are legs with rarely applied diameters, i.e. $\varnothing-0.255 \mathrm{~m} ; 0.265 \mathrm{~m}$; $0.275 \mathrm{~m} ; 0.29 \mathrm{~m}$ (usually post-repair legs), as well as new roof supports on the market, which include higher diameters: $\varnothing-0.37 \mathrm{~m} ; 0.38 \mathrm{~m} ; 0.39 \mathrm{~m} ; 0.40 \mathrm{~m} ; 0.42 \mathrm{~m}$.

It is estimated that due to increasing mining depth, legs with diameters of $\geq 0.37 \mathrm{~m}$ will be more widely used in the future, and their percentage share will increase significantly.

As regards single-telescopic legs with a mechanical extension, most of the legs that are currently applied in USCB conditions are those with diameters of 0.20 and $0.25 \mathrm{~m}$, as shown in Figure 4.

The percentage share of legs in the collective analysis by the value of overload factor in the full (type) test at the time of their placement on the market is shown in Figure 5.

The supply pressure of the support is between 25.0 and $32.0 \mathrm{MPa}$. Currently, over $90 \%$ of all roof supports used in USCB are supplied with 25.0 MPa.
In individual cases, the support is supplied with a higher pressure, which most often results from the need to maintain proper roof conditions ( $g$ index $\geq 0.8$ ).

Important elements of the powered roof support designed to work in the conditions of mining tremors are: a hydraulic control system, protection against overload and operational parameters. The vast majority of hydraulic control systems are manual. Electrohydraulic control is only used in plow systems. Studies on the introduction of the electrohydraulic control system for longwall shearers which has been developed in Poland are in progress; the solutions are likely to be implemented in the coming years [15]. Systems for monitoring the operating parameters of the PRS are being promoted and almost every new support is already equipped with such a system [16, 17]. The legs are protected against overload by using high capacity valves, the values of which are usually specified in studies on the yielding capacity of supports operating in the conditions of mining tremor hazard. 


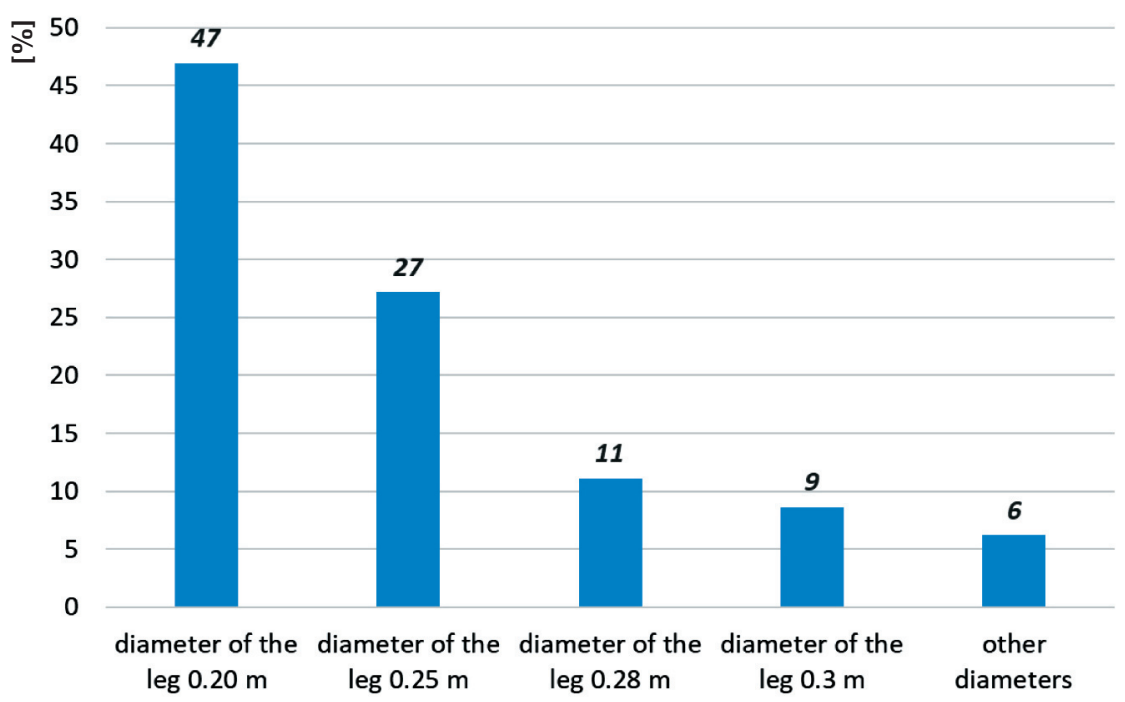

Fig. 4. Percentage share of single-telescopic legs in the analysed set by their diameter

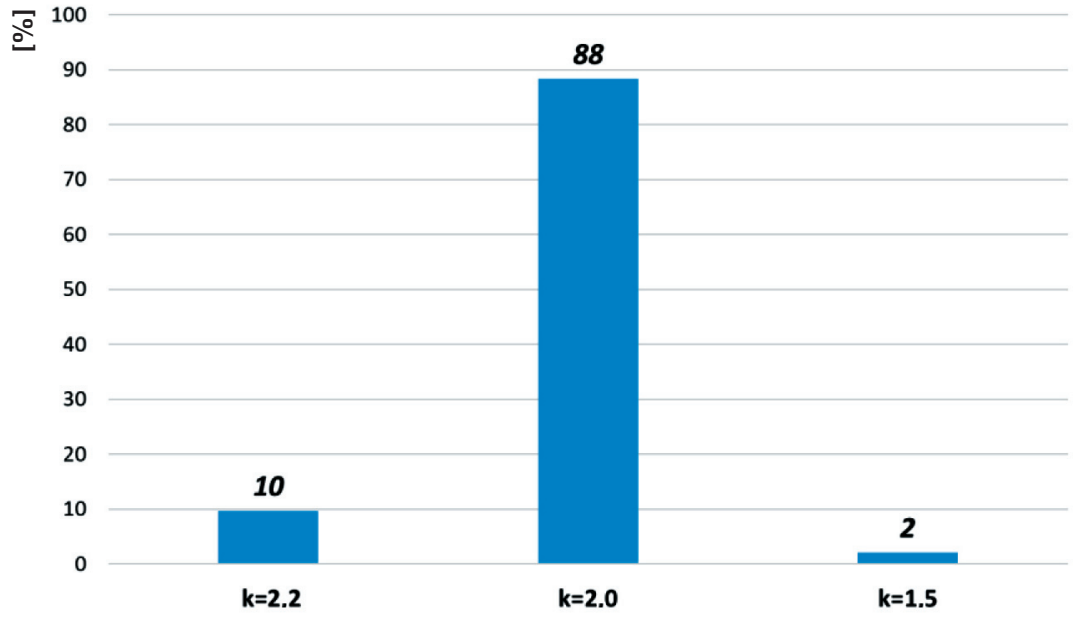

Fig. 5. Percentage of legs of powered roof supports by the value of overload factor in the full test

\section{CONCLUSIONS}

A powered roof support is one of the basic elements of the longwall system. Its proper operation has a significant impact on the efficiency and efficacy of the extraction process, as well as on general safety in the longwall. The longwall equipment usually consists of approximately 100-150 supports. The most common type of supports used in USCB mines is the shield support, and the most popular leg is the double-telescopic type with a bottom valve. The diameter of the first stage of the leg ranges from 0.2 to more than $0.4 \mathrm{~m}$, which results in more than four-time difference in the value of the applied load bearing capacity. The legs are protected against overload by hydraulic valves with appropriately selected flow rates $[4,18]$.
The new powered roof supports are equipped with legs having diameters of minimum $0.30 \mathrm{~m}$. The smallest diameters are most frequently applied in the legs of older supports manufactured before Poland's accession to the European Union.

Currently, powered roof supports are produced in compliance with EU regulations. If the supports are designed to operate in the conditions of mining tremor, they must additionally meet the requirements resulting from the OSH regulation on yielding protection of issued by the relevant Minister [1] which requires the support to take over the additional load resulting from the tremors.

The Annual Report on the State of Basic Natural and Technical Hazards in Hard Coal Mining in 2018 [19] stated that the total output from the longwalls classified as threatened by tremors amounted 
to approximately $54 \%$ of the total volume of output in Polish mines. Since the classification of a seam into an appropriate tremor hazard group is not a measure of the occurrence of high-energy rock mass tremors, it should be assumed that rock mass tremors currently affect more than $60 \%$ of the exploited seams. The degree of tremor hazard is assessed as medium, but in a few cases it is much higher. The yielding is assessed by the Central Mining Institute according to its own method, on the basis of documents provided by the ordering party.

High variability of geological and mining conditions as well as the necessity to relocate powered roof supports in the area of USCB are a premise for unifying the construction of supports (limitation of the number of varieties) and placing on the market only the ones that are prepared for operation in areas with mining tremor hazard.

The application of new supports with first-stage legs having diameters of more than $0.32 \mathrm{~m}$ has significantly reduced the possibility of performing tests under dynamic load, due to the limited technical capabilities of the leg. It is proposed to develop numerical methods and bench tests on reduced-scale models that will complement them.

In this paper, a set of data resulting from research and development works commissioned to the Central Mining Institute by mines and manufacturers of roof supports is analysed statistically. The resulting collection contains data for the years 2016-2019, and will be regularly updated.

\section{References}

[1] Rozporządzenie Ministra Energii z dnia 23 listopada 2016 r. Dz.U. nr 2017, poz. 1118, §523 ust. 1, pkt 1.

[2] Rajwa S., Prusek S., Stoiński K.: Opis metody upodatnienia zmechanizowanej obudowy ścianowej, "Bezpieczeństwo Pracy i Ochrona Środowiska w Górnictwie" 2016, 12: 3-8.

[3] Zonn W. (red.): Kopernik, astronomia, astronautyka: przewodnik encyklopedyczny, Wydawnictwo PWN, Warszawa 1973: 193.

[4] Stoiński K. (red.): Zmechanizowane obudowy ścianowe dla warunków zagrożenia wstrzasami górotworu, Wydawnictwo GIG, Katowice 2018 .
[5] Rajwa S. et al.: Praca statutowa GIG No. 12090577-152, 2007, GIG Katowice [unpublished].

[6] Prusek S., Rajwa S., Wrana A., Krzemień A.: Assessment of roof fall risk in longwall coal mines, "International Journal of Mining, Reclamation and Environment" 2016: 1-17.

[7] Prusek S., Rajwa S., Walentek A., Masny W.: Powered support selection for longwall workings in dynamic load conditions, "3rd International Symposium on Mine Safety Science and Engineering, Montreal” 2016: 13-19.

[8] Prusek S., Płonka M., Walentek A.: Applying the ground reaction curve concept to the assessment of shield support performance in longwall faces, "Arabian Journal of Geosciences" 2016, 9, 3: 1-15.

[9] Rajwa S., Masny W., Wrana A.: A comprehensive method for the selection of powered roof support in conditions of the rockburst hazard, "Wiadomości Górnicze" 2017, 1: 2-7.

[10] Rajwa S., Janoszek T., Prusek S.: Influence of canopy ratio of powered roof support on longwall working stability - A case study, "International Journal of Mining Science and Technology" 2019, 29, 4: 591-598.

[11] Biliński A., Kostyk T., Prusek S.: Zasady doboru obudowy zmechanizowanej dla wyrobisk ścianowych, "Bezpieczeństwo Pracy i Ochrona Środowiska w Górnictwie" 1997, 3: 14-17.

[12] Stoiński K.: Obudowy górnicze $w$ warunkach zagrożenia wstrzasami górotworu, Wydawnictwo GIG, Katowice 2000.

[13] Prusek S., Rajwa S., Stoiński K.: Kriterien zur Abschatzung des Risikos von Strebschaden, "Glückauf-Forschungshefte" 2005, 11: 92-95.

[14] Szurgacz D.: Próba określenia dynamicznej mocy stojaka zmechanizowanej obudowy ścianowej przeznaczonego do pracy $w$ warunkach zagrożenia wstrzasami górotworu - artykut dyskusyjny, "Prace Naukowe GIG" 2011, 10: 79-87.

[15] Szurgacz D., Brodny J.: Research on the Effectiveness of the Actuating Element of the Electro Control System for the Powered Roof Support, E3S Web of Conferences, 2018, 41, 03016.

[16] Jasiulek D., Bartoszek S., Lubryka J.: Efektywność wykorzystania i bezpieczeństwo techniczne górniczej obudowy zmechanizowanej - PRASS III, "Systemy Zasilania, Sterowania, Monitoringu i Diagnostyki" 2019, 1: 73-79.

[17] Szurgacz D., Brodny J.: Innovative visualization system designed to monitor parameters of mining systems operation, MAPE 2018, 1, 1: 361-368.

[18] Stoiński K., Prusek S., Rajwa S.: Dobór przepływów $w$ układzie zabezpieczającym stojak zmechanizowanej obudowy ścianowej - opis przypadku, XXIII International Conference TEMAG, Gliwice 2015.

[19] Kabiesz J. et al.: Raport Roczny (2018) o stanie podstawowych zagrożeń naturalnych i technicznych $w$ górnictwie węgla $\mathrm{ka}$ miennego, Wydawnictwo GIG, Katowice 2019: 95-99.

JANINA ŚWIATTEK, M.Sc., Eng. GIG Central Mining Institute plac Gwarków 1, 40-166 Katowice, Poland j.swiatek@gig.eu 


\title{
Zmechanizowane obudowy ścianowe w warunkach zagrożenia wstrząsami górotworu w GZW - stan obecny w ujęciu statystycznym
}

\begin{abstract}
Górnośląskie Zagłębie Węglowe (GZW) prowadzi eksploatację pokładów węgla głównie $w$ warunkach zagrożenia wstrząsami górotworu. Właściwy dobór obudowy do wymienionych warunków jest istotnym czynnikiem bezpiecznej i efektywnej eksploatacji. $W$ publikacji opartej na własnych analizach przeprowadzonych na grupie danych zebranych na podstawie prac zrealizowanych przez Zakład Technologii Eksploatacji, Tapań i Obudów Górniczych, Głównego Instytutu Górnictwa, przy wykorzystaniu statystyki opisowej, przedstawiono: stopień zagrożenia wstrzasami górotworu, stosowane konstrukcje obudów zmechanizowanych $w$ warunkach zagrożenia wstrząsami górotworu oraz sposób oceny ich podporności na przeciążenia dynamiczne.
\end{abstract}

Słowa kluczowe: obudowa zmechanizowana, przeciążenia dynamiczne, zagrożenie wstrzasami górotworu

\section{WSTĘP}

Zmechanizowana obudowa ścianowa wprowadzana jest na rynek zgodnie z wymogami wynikającymi z Dyrektyw Unii Europejskiej i ze zharmonizowanymi z nimi polskimi normami. Podstawowe normy określające wymagania mechaniczne dla sekcji z serii PN EN 1804 wyłączają przypadek ich obowiązywania podczas eksploatacji w warunkach zagrożenia wstrząsami górotworu. Uzupełnieniem polskich norm w zakresie dotyczącym wstrząsów górotworu jest aktualne rozporządzenie w sprawie BHP właściwego ministra [1]. Wprowadza ono wymóg upodatnienia sekcji dla warunków zagrożenia wstrząsami górotworu niezależnie od tego, według jakich przepisów została ona wprowadzona na rynek. Celem upodatnienia jest wyznaczenie bezpiecznego zakresu pracy sekcji oraz dobór zabezpieczeń przed przeciążeniem dla danych warunków geologicznogórniczych, eksploatacyjnych i technicznych sekcji [2]. Zabezpieczenie sekcji przed przeciążeniem jest dokonywane między innymi w wyniku stosowania zaworów hydraulicznych ograniczających ciśnienie w przestrzeni podtłokowej stojaka, do dopuszczalnego poziomu z uwagi na wytrzymałość mechaniczną konstrukcji.

Metoda upodatnienia stosowana w Głównym Instytucie Górnictwa (dalej GIG) jest metodą analityczną opartą na wybranych parametrach:

- górnicze - współczynnik dociążenia $n_{t z}$ i wskaźnik nośności stropu $g$,

- eksploatacyjne,
- techniczne sekcji - kinematykę sekcji, średnice stosowanych stojaków, podporność: wstępną, roboczą, nominalną; współczynnik przeciążenia $k$ oraz zastosowane zabezpieczenia zaworami hydraulicznymi.

W niniejszej publikacji podjęłam próbę opisu obecnego stanu eksploatowanych zmechanizowanych obudów w ujęciu statystycznym, obejmującym ich parametry techniczne oraz warunki pracy, na podstawie zebranej bazy danych za lata 2016-2019.

\section{PRZECIAZŻENIE SEKCJI OBUDOWY ZMECHANIZOWANEJ}

$\mathrm{Na}$ potrzeby niniejszej pracy przyjęłam definicję przeciążenia w odniesieniu do zagrożenia wstrząsami górotworu: „Przeciążenie to przekroczenie chwilowych wartości obciążenia nominalnego o więcej niż $50 \%$ dla konstrukcji i jej elementów składowych wskutek wstrząsu górotworu". Przyjęta definicja jest zgodna z zapisami polskiej normy PN-EN 1804-1,2,3+A1 oraz literatury [3].

Skutki przeciążenia to przede wszystkim utrata funkcjonalności sekcji i jej elementów (konstrukcja stalowa, stojaki hydrauliczne oraz hydraulika sterująca) lub zagrożenie ogólnie pojętego bezpieczeństwa eksploatacji (np. niekontrolowany zsuw sekcji w wyrobisku). 
Ocena przeciążenia jest dokonywana według metody GIG jako realizacja rozporządzenia właściwego ministraw zakresie przystosowania sekcji obudów zmechanizowanych do przejmowania obciążeń dynamicznych $\mathrm{w}$ drodze upodatnienia [1]. Jej celem jest wyznaczenie bezpiecznego zakresu pracy obudowy oraz dobór zabezpieczeń dla danych warunków geologiczno-górniczych, eksploatacyjnych i technicznych sekcji [2].

Metoda upodatnienia stosowana w GIG jest metodą analityczną opartą na wybranych parametrach górniczych (współczynnik dociążenia $n_{t z}$, wskaźnik nośności stropu $g$ ), eksploatacyjnych oraz technicznych sekcji i jej zabezpieczeń.

Wskaźnik dociążenia $n_{t z}$ określa przyrost obciążenia obudowy wskutek wystąpienia wstrząsu górotworu w odniesieniu do obciążeń roboczych. Zależny jest od odległości środka warstwy tąpiącej, będącej prawdopodobnym źródłem wstrząsu, od pułapu wyrobiska oraz maksymalnej prognozowanej energii wstrząsu górotworu. Zmienność wskaźnika $n_{t z}$ zawiera się w przedziale od 1,0 do 1,8 zgodnie z [4]. Współczynnik dociążenia $n_{t z}$ jest również istotnym parametrem wykorzystywanym przy określaniu wskaźnika nośności stropu $g$ [5-10]. Wskaźnik nośności stropu $g$ określa warunki utrzymania stropu i wynosi:

- $g<0,7$ - stan zagrożenia zawałem (obudowa zmechanizowana nie ma odpowiedniej rezerwy podporności, aby prawidłowo zabezpieczyć wyrobisko);
- $0,7 \leq g<0,8$ - utrudnione warunki utrzymania stropu (dopuszcza się stosowanie obudowy zmechanizowanej w danym wyrobisku, jednak należy liczyć się z możliwością występowania utrudnień w utrzymaniu stropu wyrobiska);

- $g \geq 0,8$ - poprawne warunki utrzymania stropu (obudowa jest prawidłowo dobrana pod względem podpornościowym dla danego wyrobiska).

W warunkach zagrożenia wstrząsami górotworu zaleca się, aby wskaźnik $g$ był $\geq 0,8$, a tym samym zapewniał poprawne utrzymanie stropu. Zaznaczyć jednak należy, że zależność pomiędzy wskaźnikiem $g$ a współczynnikiem dociążenia $n_{t z}$ nie jest funkcją linową i należy je rozpatrywać indywidualnie dla każdego przypadku planowanej do uruchomienia ściany oraz planowanej do zastosowania zmechanizowanej obudowy ścianowej.

Stopień zagrożenia wstrząsami górotworu wyrobiska ścianowego na podstawie wartości współczynnika dociążenia $n_{t z}$ można określić za pomocą tabeli 1 .

Kształtowanie się współczynnika dociążenia $n_{t z}$ w latach 2016-2019 przedstawiono graficznie na rysunku 1. Dane obejmują 266 przypadków ścian prowadzonych w warunkach GZW, analizowanych przez Główny Instytut Górnictwa w ramach wykonywanych prac badawczo-rozwojowych, zlecanych przez kopalnie i producentów obudów, dotyczących doboru obudowy zmechanizowanej i określenia warunków jej upodatnienia do danych warunków geologiczno-górniczych.

Tabela 1

Stopień zagrożenia wstrząsami górotworu wyrobiska ścianowego na podstawie wartości współczynnika dociążenia $n_{t z}$ [4]

\begin{tabular}{|l|c|c|c|c|c|}
\hline Wartość wskaźnika $\boldsymbol{n}_{\boldsymbol{t} \boldsymbol{z}}$ & $1,0-1,1$ & $1,1-1,2$ & $1,2-1,3$ & $1,3-1,4$ & $>1,4$ \\
\hline Zagrożenie wyrobiska & brak & słabe & średnie & silne & bardzo silne \\
\hline
\end{tabular}

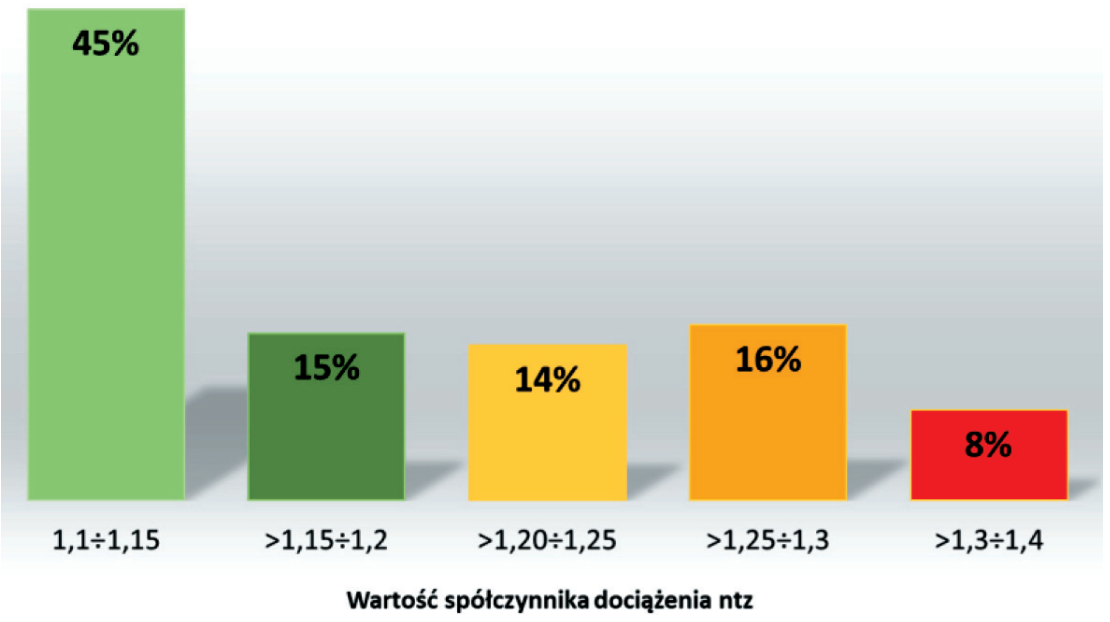

Rys. 1. Wspótczynnik docią̇enia $n_{t z}$ w latach 2016-2019 wedlug GIG 
Z powyższych danych wynika, że $29 \%$ wyrobisk ścianowych prowadzonych jest w średnim stopniu zagrożenia tąpaniami, zaś $8 \% \mathrm{w}$ silnym stopniu zagrożenia wstrząsami górotworu. Uwzględniając obecne pogarszające się warunki geologiczno-górnicze w GZW, należy uznać, że procent ścian prowadzonych w silnym stopniu zagrożenia wstrząsami górotworu będzie się zwiększał.

Upodatnienie sekcji zgodnie z metodyką GIG wyznaczane jest na podstawie modelu górotworu naruszonego według A. Bilińskiego oraz modelu płaskiego sekcji o stałych skupionych i jednym stopniu swobody z zależności $[2,4,11-13]$ :

$$
\begin{aligned}
f(t) & =\frac{1}{\cos (90-\alpha)} . \\
& \cdot\left(F_{w}+F_{d}\left(1+k_{d} e^{-\delta t} \sin (\omega t-\varphi)\right)[\mathrm{N}]\right.
\end{aligned}
$$

gdzie:

$$
\begin{aligned}
f(t), F_{w}, F_{d}- & \text { siły odpowiednio: obciążenia stoja- } \\
& \text { ka, wstępna i dynamiczna }[\mathrm{N}], \\
\delta- & \text { współczynnik tłumienia układu }\left[\mathrm{s}^{-1}\right], \\
k_{d}- & \text { współczynnik obliczeniowy, } \\
\omega- & \text { pulsacja układu }\left[\mathrm{s}^{-1}\right], \\
\varphi- & \text { kąt przesunięcia przebiegu siły w sto- } \\
& \text { jaku w odniesieniu do siły obciążają- } \\
& \text { cej [rad], } \\
\alpha- & \text { kąt pochylenia stojaka względem } \\
& \text { spągnicy [ } \left.{ }^{\circ}\right] .
\end{aligned}
$$

Według podanej metody dla każdego przypadku oblicza się maksymalną siłę i odnosi się ją do nominalnej podporności stojaka, dla danej roboczej wysokości obudowy, wartości wskaźnika $n_{t z}$ oraz przepływu w układzie zabezpieczającym stojak przed przeciążeniem.

Dodatkowo przy stropach trudnorabowalnych (nieprzechodzących w stan zawału za sekcjami obudów zmechanizowanych) proponuje się przeprowadzenie dodatkowych obliczeń z wykorzystaniem oceny mocy układu górotwór-sekcja według zależności (2) [4, 14], celem sprawdzenia przepływów w układzie zabezpieczającym stojak.

$$
Q \geq \frac{F_{r}\left(n_{t z}^{2}-n_{t z}\right)}{2 P_{r} \cos \alpha} \cdot 6 \cdot 10^{4}\left[\mathrm{dm}^{3} \min ^{-1}\right]
$$

gdzie:

$Q$ - przepływ w układzie zabezpieczającym stojak,

$F_{r}$ - podporność robocza obudowy [N],

$n_{t z}$ - współczynnik dociążenia obudowy,

$P_{r}-$ podporność nominalna stojaka [N].

\section{PARAMETRY \\ EKSPLOATACYJNE I TECHNICZNE \\ AKTUALNIE STOSOWANYCH OBUDÓW ZMECHANIZOWANYCH}

W latach 2016-2019 Zakład Technologii Eksploatacji, Tąpań i Obudów Górniczych, GIG, wykonał ponad 550 prac badawczo-rozwojowych, w tym 266 dotyczących określenia warunków upodatnienia sekcji oraz możliwości jej stosowania w danych warunkach geologiczno-górniczych.

$\mathrm{Z}$ przeprowadzonej analizy wykonanych opracowań dotyczących warunku stosowania sekcji obudów w pokładach zagrożonych wstrząsami górotworu wynika, że w warunkach GZW najczęściej stosowane są sekcje obudowy typu podporowo-osłonowego dwustojakowe. Najczęściej stosowane stojaki hydrauliczne to dwuteleskopowe $\mathrm{z}$ zaworem dennym, a ich udział w całej analizowanej grupie wynosi aż 73\% (rys. 2).

Stojaki jednoteleskopowe z przedłużaczem mechanicznym są już coraz rzadziej stosowane, jednak ciągle stanowią liczną grupę, a ich udział procentowy klasyfikuje je na drugim miejscu i wynosi 16\%.

Grupę 7\% stanowią stojaki dwuteleskopowe z tzw. trzecim tłokiem. Pozostałe 5\% zajmują stojaki, których udział w całej analizowanej grupie był najmniejszy i zaliczyć do nich można stojaki dwuteleskopowe z zaworem dennym i przedłużaczem mechanicznym/ hydraulicznym oraz stojaki z cieczą w tłoczysku.

Procentowy podział stojaków dwuteleskopowych ze względu na ich średnicę I stopnia w analizowanym zbiorze przedstawia rysunek 3 .

Obecnie najpowszechniej stosowane w GZW są stojaki o średnicach I stopnia równych 0,30 i $0,32 \mathrm{~m}$, co związane jest $\mathrm{z}$ pogarszającymi się warunkami geologiczno-górniczymi. Liczną grupę stanowią także stojaki o średnicy I stopnia $0,25 \mathrm{~m}$, co związane jest z remontami wcześniej eksploatowanych obudów.

Obecnie ponad $60 \%$ eksploatacji odbywa się w warunkach zagrożenia wstrząsami górotworu, co potwierdza fakt, że kopalnie coraz częściej zakupują obudowy zmechanizowane ze stojakami o średnicach $\geq 0,30 \mathrm{~m}$ w celu uzyskania większej podporności obudowy oraz zapewnienia poprawnych warunków utrzymania stropu wyrobiska.

Pozostałe stosowane średnice, które stanowią 8\% analizowanych przypadków, to stojaki o średnicach I stopnia rzadko stosowanych tj. $\varnothing-0,255 \mathrm{~m} ; 0,265 \mathrm{~m}$; $0,275 \mathrm{~m} ; 0,29 \mathrm{~m}$ (zwykle są to stojaki poremontowe), a także nowych obudów dopiero wprowadzanych na rynek, do których zaliczamy średnice: $\varnothing-0,37 \mathrm{~m}$; $0,38 \mathrm{~m} ; 0,39 \mathrm{~m} ; 0,40 \mathrm{~m} ; 0,42 \mathrm{~m}$. 


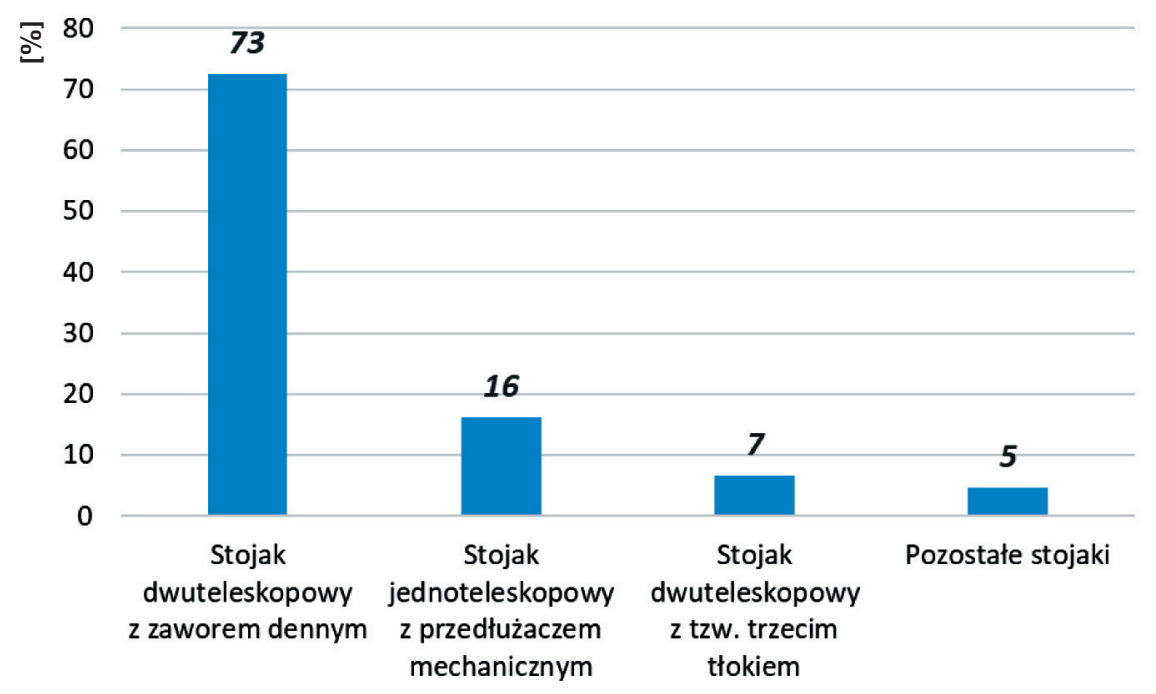

Rys. 2. Procentowy udział stojaków różnych typów $w$ analizowanej populacji sekcji zmechanizowanych obudów ścianowych w latach 2016-2019

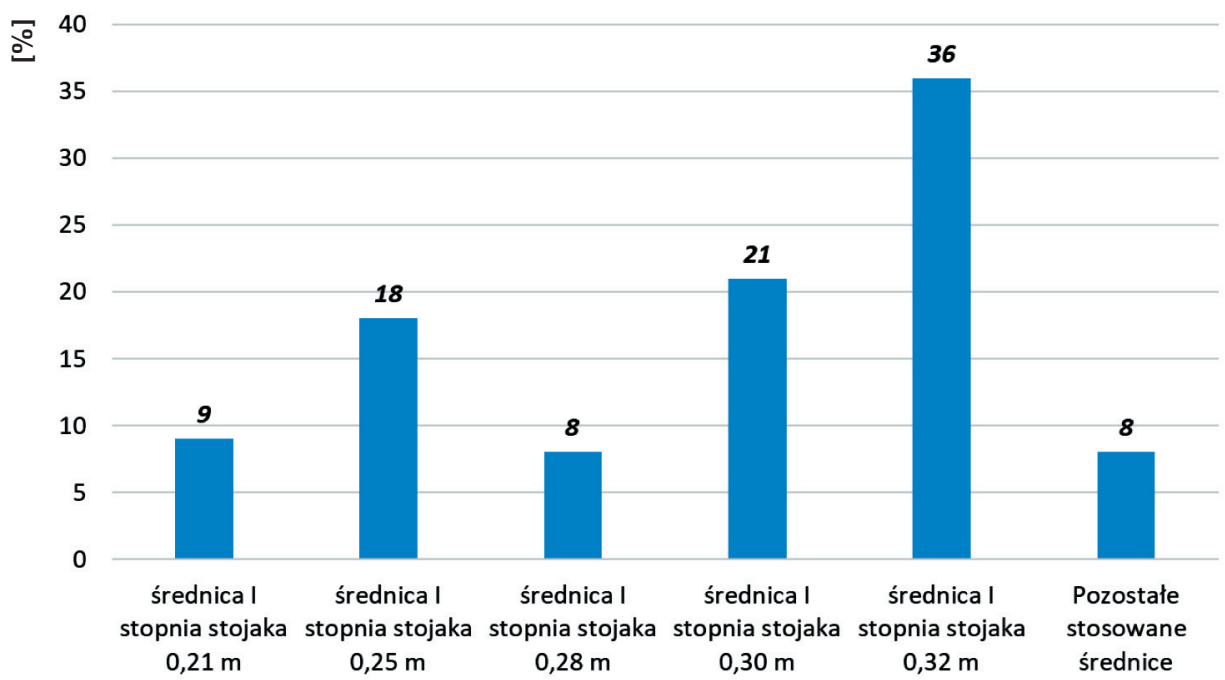

Rys. 3. Procentowy udziat stojaków dwuteleskopowych ze względu na średnicę I stopnia, analizowanego zbioru

Ze względu na pogarszające się warunki geologiczno-górnicze związane głównie z coraz większą głębokością eksploatacji szacuje się, że stojaki o średni-cach $\geq 0,37 \mathrm{~m}$ będą coraz powszechniej stosowane w przyszłości, a ich udział procentowy znacznie się zwiększy.

Wśród stojaków jednoteleskopowych obecnie w warunkach GZW najczęściej stosuje się stojaki o średnicach $0,20 \mathrm{~m}$ i $0,25 \mathrm{~m}$, co przedstawiono na rysunku 4 .

Procentowy udział stojaków w analizie zbiorczej ze względu na wartość współczynnika przeciążenia w badaniu pełnym (typu) przy wprowadzaniu na rynek przedstawiono na rysunku 5 .

Według dokumentacji techniczno-ruchowych sekcji zmechanizowanych obudów ścianowych (DTR) ciśnienie zasilania zawiera się $\mathrm{w}$ przedziale $25,0-32,0 \mathrm{MPa}$. Aktualnie ponad $90 \%$ wszystkich obudów stosowanych w GZW zasilana jest ciśnieniem 25,0 MPa.
W poszczególnych przypadkach (przy uwzględnieniu zaleceń zawartych w DTR) sekcje zasilane sa ciśnieniem wyższym, co najczęściej wynika z konieczności utrzymania poprawnych warunków stropowych (wskaźnik $g \geq 0,8$ ).

Istotnym elementem sekcji zmechanizowanej obudowy ścianowej eksploatowanej w warunkach zagrożenia wstrząsami górotworu są systemy sterowania, zabezpieczania przed przeciążeniem stojaka oraz kontroli parametrów roboczych. Sterowanie w zdecydowanej większości to hydrauliczne przyległe, bezpośrednie lub pilotowe. Elektrohydrauliczne występuje jedynie w kompleksach strugowych. Trwają prace studialne nad wprowadzeniem opracowanego w Polsce systemu sterowania elektrohydraulicznego do kompleksów kombajnowych, z dużym prawdopodobieństwem nastąpi to w najbliższych latach [15]. 
Upowszechniane są systemy monitoringu parametrów roboczych sekcji, praktycznie każda nowa obudowa jest już w taki system wyposażona [16, 17]. Zabezpieczenie stojaków przed przeciążeniem polega na zastosowaniu zaworów o dużych przepustowościach, których wartości najczęściej określane są w opracowaniach dotyczących upodatnienia sekcji dla warunków zagrożenia wstrząsami górotworu.

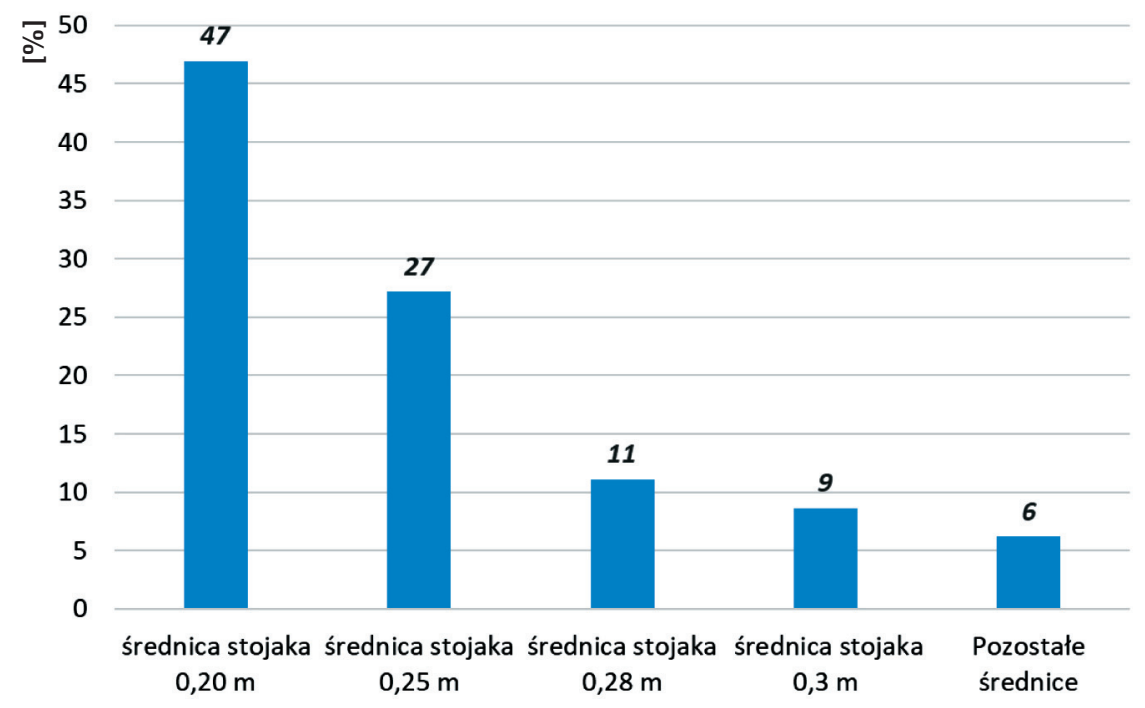

Rys. 4. Procentowy udziat stojaków jednoteleskopowych w analizowanym zbiorze ze względu na ich średnicę

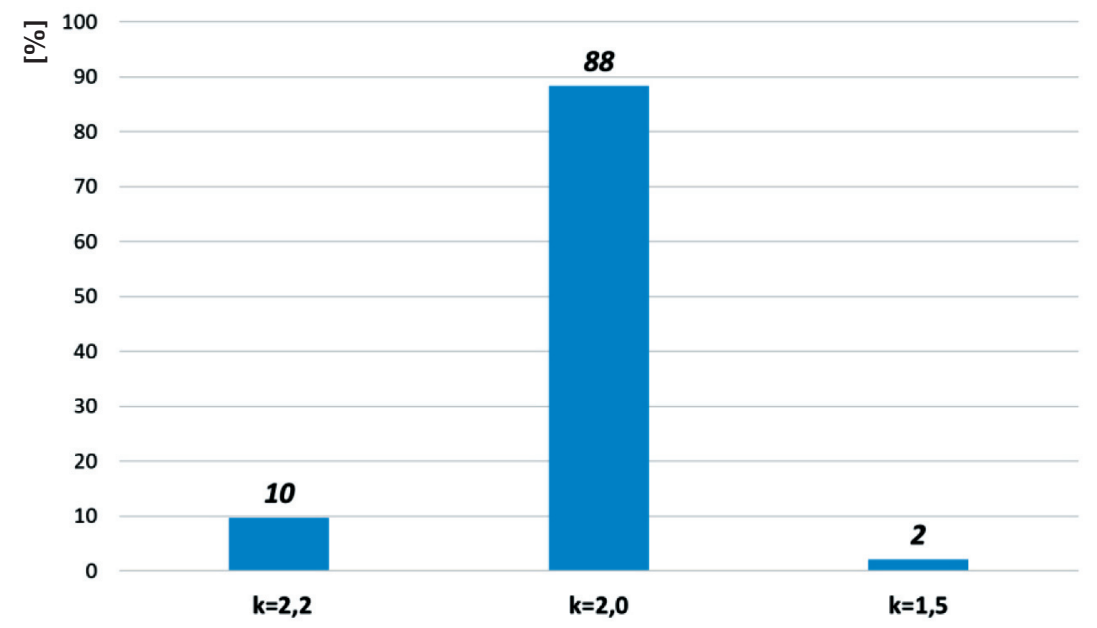

Rys. 5. Procentowy udziat stojaków obudów zmechanizowanych ze względu na wartość wspótczynnika przeciażenia w badaniu petnym

\section{WNIOSKI}

Zmechanizowana obudowa ścianowa jest jednym z podstawowych elementów kompleksu ścianowego. Prawidłowe jej funkcjonowanie ma istotny wpływ na efektywność wydobycia, a także na ogólnie pojęte bezpieczeństwo w ścianie. W skład kompleksu ścianowego wchodzi zwykle około 100-150 sztuk sekcji, mających wspólne sterowanie i zasilanie. Najczęściej stosowanym w GZW typem sekcji jest podporowo-osłonowa dwustojakowa. Stojaki są najczęściej dwuteleskopowe z zaworem dennym. Średnice I stopnia stojaka decydujące o podporności sekcji zawierają się w przedziale od $0,2 \mathrm{~m}$ do ponad $0,4 \mathrm{~m}$, co skutkuje ponad czterokrotną różnicą w zastosowanej podporności. Stojaki przed przeciążeniem są zabezpieczane zaworami hydraulicznymi o odpowiednio dobranych przepływach $[4,18]$.

$\mathrm{Z}$ uwagi na pogarszające się warunki geologiczno-górnicze w nowych, wprowadzanych na rynek sekcjach stosuje się stojaki o średnicach I stopnia co najmniej 0,30 m. Najmniejsze średnice występują najczęściej w stojakach stosowanych w sekcjach wprowadzanych na rynek przed wejściem Polski do Unii Europejskiej. 
Aktualnie na rynek sekcje obudów zmechanizowanych są wprowadzane zgodnie z prawem unijnym. Jeżeli sekcje są przeznaczone do pracy w warunkach zagrożenia wstrząsami górotworu, muszą dodatkowo spełnić wymagania dotyczące ich upodatnienia wynikające $\mathrm{z}$ rozporządzenia $\mathrm{w}$ sprawie BHP odpowiedniego ministra [1]. Upodatnienie stawia wymóg przejęcia przez sekcję dodatkowych obciążeń wynikających ze wstrząsów górotworu.

Zgodnie $\mathrm{z}$ raportem rocznym o stanie podstawowych zagrożeń naturalnych i technicznych w górnictwie węgla kamiennego z 2018 roku [19], wydobycie ogółem z rejonów zaliczonych do zagrożonych tąpaniami wynosiło około 54\% ogólnej wielkości wydobycia. Ponieważ zaliczenie pokładu lub jego części do odpowiedniego stopnia zagrożenia tąpaniami nie jest miernikiem wystąienia lub nie, wysokoenergetycznego wstrząsu górotworu, przyjąć należy, że wstrząsy górotworu dotyczą obecnie ponad $60 \%$ eksploatowanych pokładów. Stopień zagrożenia wstrząsami górotworu oceniany jest jako średni, jednak w nielicznych przypadkach stopień zagrożenia jest znacznie większy. Ocenę upodatnienia dokonuje Główny Instytut Górnictwa według metody własnej na podstawie dostarczonych przez zleceniodawcę dokumentów.

Duża zmienność warunków geologiczno-górniczych oraz konieczność relokacji obudów zmechanizowanych w obszarze GZW jest przesłanką do ujednolicenia konstrukcji sekcji (ograniczenia ilości odmian) i wprowadzenia na rynek wyłącznie sekcji przygotowanych do pracy w warunkach zagrożenia wstrząsami górotworu.

Wprowadzenie na rynek i do eksploatacji sekcji ze stojakami I stopnia o średnicach ponad $0,32 \mathrm{~m}$ ograniczyło w znacznym stopniu możliwości prowadzenia badań pod obciążeniem dynamicznym, z uwagi na ograniczone możliwości techniczne stanowisk. Proponuje się rozwijanie metod numerycznych, a jako ich uzupełnienie badań stanowiskowych na modelach w pomniejszonej skali.

W niniejszej publikacji poddano analizie w ujęciu statystycznym zbiór danych powstały w wyniku prowadzenia prac badawczo-rozwojowych zlecanych Głównemu Instytutowi Górnictwa przez kopalnie oraz producentów obudów. Powstały zbiór zawiera dane za lata 2016-2019 i będzie on systematycznie uzupełniany.

\section{Literatura}

[1] Rozporzadzenie Ministra Energii z dnia 23 listopada 2016 r. Dz.U. nr 2017, poz. 1118, §523 ust. 1, pkt 1.

[2] Rajwa S., Prusek S., Stoiński K.: Opis metody upodatnienia zmechanizowanej obudowy ścianowej, „Bezpieczeństwo Pracy i Ochrona Środowiska w Górnictwie”, 2016, 12: 3-8.

[3] Zonn W., red.: Kopernik, astronomia, astronautyka: przewodnik encyklopedyczny. Wydawnictwo PWN, Warszawa 1973: 193.

[4] Stoiński K. red.: Zmechanizowane obudowy ścianowe dla warunków zagrożenia wstrzasami górotworu, Wydawnictwo GIG, Katowice 2018.

[5] Rajwa S. et al.: Praca statutowa GIG No. 12090577-152, 2007, GIG Katowice [praca niepublikowana].

[6] Prusek S., Rajwa S., Wrana A., Krzemień A.: Assessment of roof fall risk in longwall coal mines, „International Journal of Mining, Reclamation and Environment" 2016: 1-17.

[7] Prusek S., Rajwa S., Walentek A., Masny W.: Powered support selection for longwall workings in dynamic load conditions, „3rd International Symposium on Mine Safety Science and Engineering, Montreal" 2016: 13-19.

[8] Prusek S., Płonka M., Walentek A.: Applying the ground reaction curve concept to the assessment of shield support performance in longwall faces, „Arabian Journal of Geosciences”, 2016, 9, 3: 1-15.

[9] Rajwa S., Masny W., Wrana A.: A comprehensive method for the selection of powered roof support in conditions of the rockburst hazard, „Wiadomości Górnicze” 2017, 1: 2-7.

[10] Rajwa S., Janoszek T., Prusek S.: Influence of canopy ratio of powered roof support on longwall working stability - A case stu$d y$, „International Journal of Mining Science and Technology", 2019, 29, 4: 591-598.

[11] Biliński A., Kostyk T., Prusek S.: Zasady doboru obudowy zmechanizowanej dla wyrobisk ścianowych, „Bezpieczeństwo Pracy i Ochrona Środowiska w Górnictwie”, 1997, 3: 14-17.

[12] Stoiński K.: Obudowy górnicze $w$ warunkach zagrożenia wstrzasami górotworu, Wydawnictwo GIG, Katowice 2000.

[13] Prusek S., Rajwa S., Stoiński K.: Kriterien zur Abschatzung des Risikos von Strebschaden, „Glückauf-Forschungshefte” 2005, 11: 92-95.

[14] Szurgacz D.: Próba określenia dynamicznej mocy stojaka zmechanizowanej obudowy ścianowej przeznaczonego do pracy $w$ warunkach zagrożenia wstrzasami górotworu - artykut dyskusyjny, „Prace Naukowe GIG” 2011, 10: 79-87.

[15] Szurgacz D., Brodny J.: Research on the Effectiveness of the Actuating Element of the Electro Control System for the Powered Roof Support, E3S Web of Conferences, 2018, 41, 03016.

[16] Jasiulek D., Bartoszek S., Lubryka J.: Efektywnośc wykorzystania i bezpieczeństwo techniczne górniczej obudowy zmechanizowanej - PRASS III, „Systemy Zasilania, Sterowania, Monitoringu i Diagnostyki” 2019, 1: 73-79.

[17] Szurgacz D., Brodny J.: Innovative visualization system designed to monitor parameters of mining systems operation, MAPE 2018, 1, 1: 361-368.

[18] Stoiński K., Prusek S., Rajwa S.: Dobór przeptywów w układzie zabezpieczającym stojak zmechanizowanej obudowy ścianowej - opis przypadku, XXIII International Conference TEMAG, Gliwice 2015.

[19] Kabiesz J. et al.: Raport Roczny (2018) o stanie podstawowych zagrożeń naturalnych $i$ technicznych $w$ górnictwie weggla kamiennego, Wydawnictwo GIG, Katowice 2019: 95-99.

mgr inż. JANINA ŚWIĄTEK

Gtówny Instytut Górnictwa

plac Gwarków 1, 40-166 Katowice

j.swiatek@gig.eu 